\title{
Effect of Luffa Aegyptiaca on Acetyl Choline Induced Contractions in Chick Ileum Preparation
}

\author{
Aboobucker*, Kavimani. $\mathrm{S}^{1}$, Jegadeesan. $\mathrm{M}^{2}$ \\ *2, Dept of Environmental and Herbal Science, Tamil University, Thanjavur \\ ${ }^{I}$ Dept.of Pharmacology, Mother Theresa Post graduate and Research Institute of Health Sciences, Puducherry- \\ 605006.
}

\begin{abstract}
Luffa aegyptiaca belongs to family cucurbitaceae. The other name of this plant is vietanamese gourd or vietanamese luffa. The young fruit is eaten as vegetable. The fruit contains phytoconstituents such as carbohydrates, fat, protein, vitamins and minerals. The fruit section of Luffa aegyptiaca may be allowed to mature and used as bath or kitchen sponge after being processed to remove everything but network of xylem or fibres. The Luffa aegyptiaca fruit juice have been reported as a source of peroxidase. In the present study, the methanolic extract of Luffa aegyptica potentiated the Ach induced contractions in isolated chick ileal preparation. The log dose response curve of Ach is shifted towards the left hand side in presence of the extract. Keywords: Acetylcholine, Chick ileum, Luffa aegyptiaca, Physostigmine
\end{abstract}

\section{Introduction}

Sponge gourd (Luffa aegyptiaca Mill.) belongs to the family of Cucurbitaceae. It is a crawling plant that grows wild and on abandoned buildings and fence walls in Nigeria (Dairo, 2008). The plant with yellow flowers bears fruits that are cucumber-shaped but larger in size and contain a fibrous sponge in which the hard black seeds are enmeshed (Dairo, 2008). In oriental medicine, L. aegyptiaca is used in the treatment of fever, enteritis, swell etc. The extracts from vines are also used as ingredients in cosmetics and medicine and the immature fruits are used as vegetable. One of the main uses of sponge gourd, however, is in the cosmetic industry for production of various bath and cosmetics products (Tanobe et al., 2005). The seed also contains oil with potential for a range of applications. In oriental medicine $L$. aaegyptiaca is used in the treatment of fever, enteritis, swell etc. The aim of present study is to find out the effect of methanolic extract of L. aegyptiaca on Ach induced contraction in isolated ileum of chicken.

\subsection{Isolated Chick Ileum- A Brief Introduction}

Chick ileum is an isolated tissue preparation used for bioassay of drugs. Experiments with this isolated chick ileum are chiefly designed to understand the receptor action of drugs in-vitro with an emphasis to appreciate the concepts of graded response, nature of antagonism, potentiation and dose ratios.(Kulkarni, 1999). The chick ileum contains cholinergic muscarinic receptors, serotonergic receptors, histaminic $\left(\mathrm{H}_{1} \& \mathrm{H}_{2}\right)$ receptors, prostaglandin receptors ( $\mathrm{PGE}, \mathrm{PGE}_{2}, \mathrm{PGF}_{2 \alpha}$ ), progesterone receptors, tachykinin receptors and motilin receptors(Hansen et al.,1989;Salolaa et al.,1989;Pasanen et al.,1997;Kitazawa et al.,1997;Liu and Burcher 2001; Martin et al.,1993; Pust et al.,1996).

\subsection{Drugs Acting On Chick Ileum}

- Histamine $\left(\mathrm{H}_{1}\right)$ produces contraction. $\mathrm{H}_{2}$ receptors produce relaxation of the ileum(Chand et al.,1978).

- Metiamide $\left(\mathrm{H}_{2}\right.$ receptor antagonist) blocked histamine $\left(\mathrm{H}_{2}\right)$ induced relaxation and potentiate contractile response to histamine $\left(\mathrm{H}_{1}\right)($ Pasanen et al., 1997).

- Tachykinin produce contraction of the chick ileum(Kitazawa et al.,1997).

- Chicken motilin produce contraction in the smooth muscle of ileum and is blocked by atropine and tetradoxin(Liu and Burcher 2001).

- Galanin contracts the intestinal smooth muscle isolated from leghorn hens.Nifedipine inhibits the contractile response of the smooth muscle to galanin(Martin et al.,1993).

- Cisapride(5-HT 4 -partial agonist) decreased effects of both 5-HT and 5-MOT(Pust et al.,1996).

- Acetylcholine produce contraction of the ileum by acting through muscarinic receptors(Chattopadhyay et al.,1992).

- Polyphloretin phosphate inhibited contraction to $\mathrm{PGE}_{1}, \mathrm{PGE}_{2}, \mathrm{PGF}_{2 \alpha}$ (Chattopadhyay et al.,1992).

- 5-HT elicited ileal contraction and is decreased in presence of tetradoxin.

- Atropine, ketanserine, metthylsergide, methiothepine reduce the response to5-HT.

- 5-methoxy tryptamine(a mixed 5- $\mathrm{HT}_{1}, 5-\mathrm{HT}_{2}$ and 5- $\mathrm{HT}_{4}$ agonist)produce contraction. 
- Atropine at lower concerntrations selectively antagonize Ach. At higher doses inhibits histamine.

- Mepyramine specifically inhibited histamine $\left(\mathrm{H}_{1}\right)$ induced contraction.

- Methylsergide selectively antagonmized 5-HT induced contraction.

- Sodium meclofenamate at larger doses exhibited various degrees of non specific blockade of histamine, acetylcholine and 5-HT.

- Phenylbutazone antagonized Ach,histamine and 5-HT induced contractions.

- Diethyl carbamazine citrate at larger doses strongly antagonized histamine,Ach and 5-HT induced contractions.

\section{Materials And Methods:}

\section{Methanolic extract of Luffa aegyptiaca}

Preparation of physiological salt solution (PSS):

All values are in $\mathrm{g} / \mathrm{l}$. Weighed accurate quantity of the ingredients and dissolved in one liter distilled water such that the physiological solution prepared should be clear, and if turbid it is advised to prepare fresh solution

\begin{tabular}{|l|l|}
\hline \multicolumn{1}{|c|}{ Compound } & \multicolumn{1}{c|}{ Tyrode } \\
\hline $\mathrm{Nacl}$ & 8.0 \\
\hline $\mathrm{Kcl}$ & 0.2 \\
\hline $\mathrm{CaCl}_{2}$ & 0.2 \\
\hline $\mathrm{MgCl}_{2}$ & 0.10 \\
\hline $\mathrm{NaHCO}_{3}$ & 1.0 \\
\hline $\mathrm{NaH}_{2} \mathrm{Po}_{4}$ & 0.05 \\
\hline $\mathrm{Glucose}^{\prime}$ & \\
\hline
\end{tabular}

before the start of the experiment.

- Fresh entire gastrointestinal tract of healthy cock was obtained from a slaughter house in Puducherry.

- The caecum was lifted forwards and the ileocaecal junction was identified.

- A few centimeters of the ileal portion was cut and removed and immediately placed it in the watch glass containing physiological salt solution. The mesentery and adhering tissues were removed with gentle care. Utmost care was taken to avoid any damage to the gut muscle. The ileum was cut into small segments of 2$3 \mathrm{~cm}$ long.

- To one piece of ileum the thread was tied to top and bottom ends without closing the ileum, and mounted the tissue in the organ bath containing tyrode solution maintained at $32-35^{\circ} \mathrm{C}$ and bubbled with air. The magnification from 5-7 folds and bath volume of about $25 \mathrm{ml}$ was maintained, and the tissue was allowed to equilibrate for $30 \mathrm{~min}$ before adding Acetylcholine to the organ bath.

- The Acetylcholine(Ach) induces the contraction in the ileal smooth muscles which were recorded on Kymograph by using frontal writing lever. Contact time of $30 \mathrm{sec}$, and $5 \mathrm{~min}$ time cycle was kept for proper recording of the responses.

- The CRC was recorded till ceiling effect to Acetylcholine was obtained and the height of the response was measured.

- Various parameters were changed and responses were taken as magnification value $3 \& 5$, load/tension 0.5 , $1.0 \& 1.5 \mathrm{gm}$ and tissue length $1.5,2.0 \mathrm{~cm}$.

- The experiment was repeated in presence of $10 \mu \mathrm{g} / \mathrm{ml}$ of physostigmine and $100 \mu \mathrm{g} / \mathrm{ml}$ methanolic extract of Luffa aegyptica

- The $\log$ doses and response height in $\mathrm{mm}$ were calculated and the concentration response curves of acetylcholine in the absence and presence of test drugs were plotted with log doses on $\mathrm{X}$-axis and response height on $\mathrm{Y}$-axis respectively.

- The effect of extract on CRC of Ach using chick ileum was observed based upon the shift of the curve in presence of extract whereas leftwards shift denotes the potentiation effect and rightwards shift denotes the inhibitory effect on Ach.

\section{Results And Discussion}

$160 \mu \mathrm{g}$ of Ach produced $51 \mathrm{~mm}$ of response. Whereas in presence of physostigmine and methanolic extract of L. aegyptiaca, the response of Ach have been increased to 77 and $98 \mathrm{~mm}$ respectively. The log dose Vs response curve have been plotted. The log dose response curve of Ach have been shifted towards left hand side in presence of physostigmine and methanolic extract of L. aegyptiaca indicates their agonistic activity. The agonistic activity of extract is more than that of physostigmine.Further studies are required to elucidate its mechanism. 


\section{FIGURE 1}

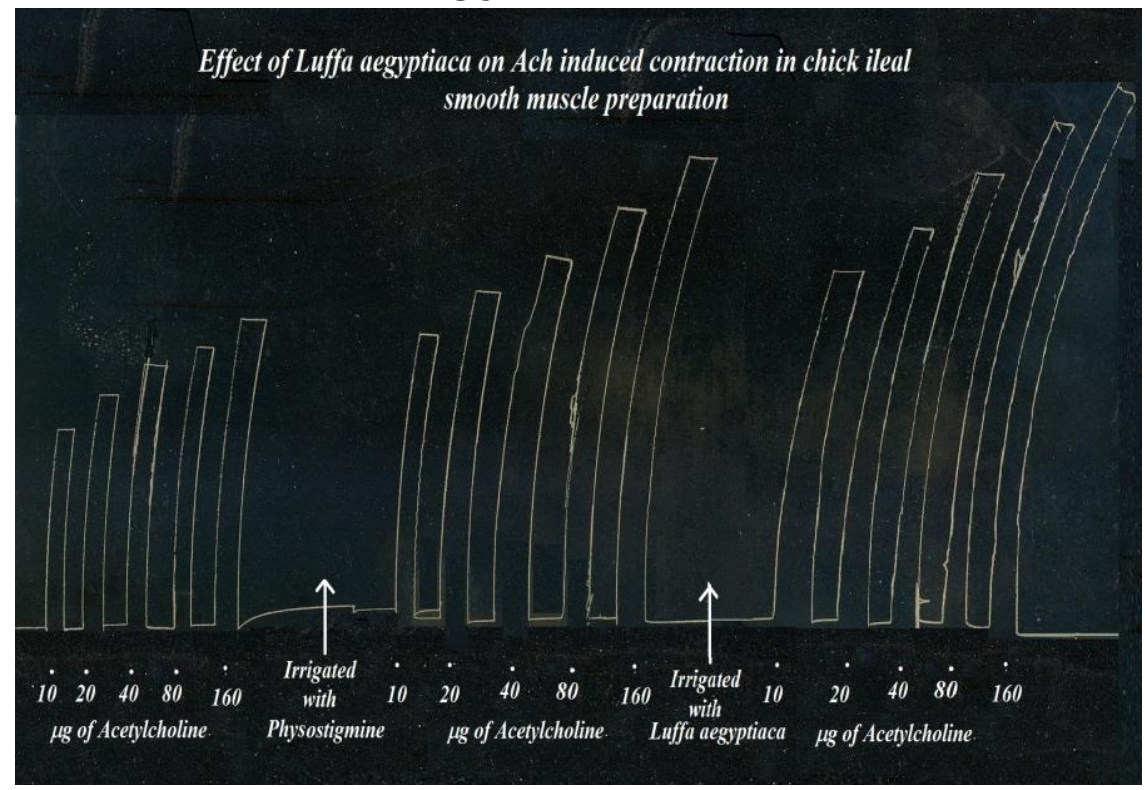

\section{FIGURE 2}

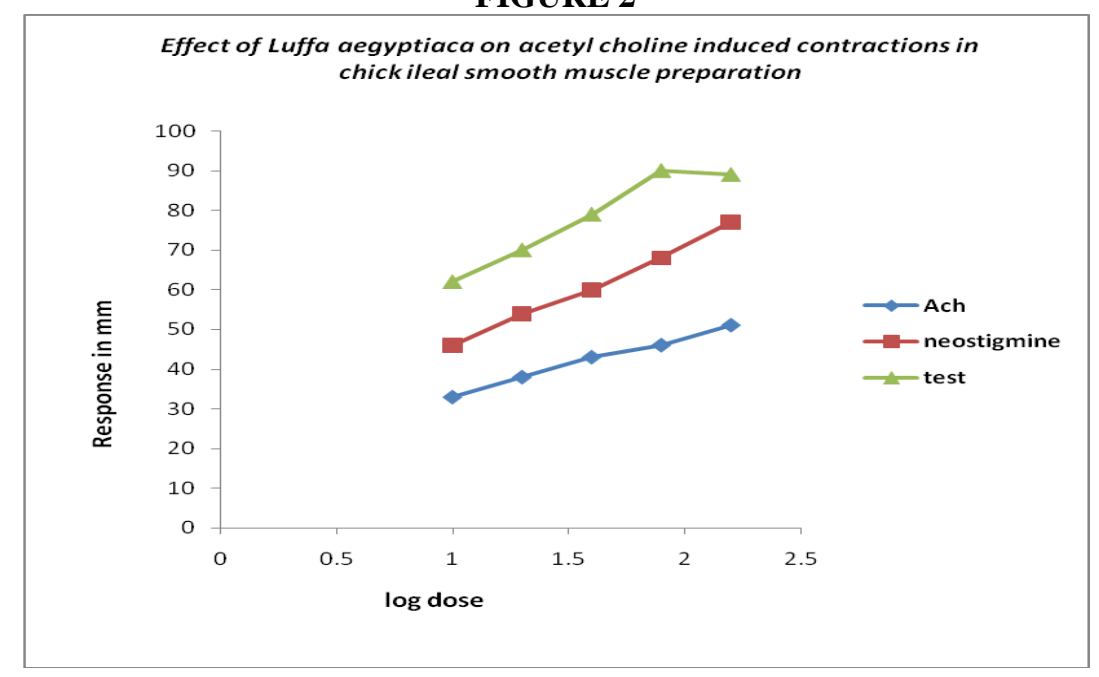

References

[1]. Ashby JP and Speake RN.1975.Insulin and glucagon secretion from isolated islets of langerhans:The effect of calcium ionophores.J.Biochem.1975;150:89-96.

[2]. Chand $\mathrm{N}$.,Laszlo de Roth.Ocurrence of $\mathrm{H}_{2}$ inhibitory histamine receptors in chicken ileum.European Journal of pharmacology.1978;52(1):143-145.

[3]. Charles MA .,Lawecki J .,Pictet T and Grodsky GM.Insulin secretion:Interrelationships of glucose,adenosine 3',5'-monophosphate and calcium.J.Biol.Chem.1975;250:6134-6140.

[4]. Charles R Craig and Robert E Stitzel.Editor.Modern pharmacology with clinical applications.6 ${ }^{\text {th }}$ Edition.Lipinscott Williams and Wilkins;2012.Drugs affecting the endocrine system.CH-67:774,765.

[5]. Chattopadhyay .,Roy RK .,Das AK .,Chaudhuri S .,Lahiri HL .,Maiti SP .,Das MM.Comparative studies of the effects of calcium channel blockers on isolated skeletal muscle preparation.Indian Journal of Pharm,acology.1992;24:233-234.

[6]. Dairo, F.A.S. 2008. Performance and haematological evaluation of weaner rabbits fed Loofah gourd seed meal (Luffa cylindrica \{M.J.Roem\}). Afr. J. Food Agri. Nutr. Dev., 8 (4): 451-463

[7]. Grodsky GM and Bennett L.Cation requirements for insulin secretion in the isolated perfused pancreas.Diabetes.1966;15:910-913.

[8]. Hansen BM .,Bindslev N .Serotonin receptors for chloride secretion in hen colon.Comparative Biochemistry and physiology.1989;94(1):189-197.

[9]. Karl RC .,Zawalich WS.,Ferrendelli JA and Maatschinsky FM.The role of $\mathrm{Ca}^{++}$and adenosine 3',5'-monophosphate and calcium.J.Biol.Chem.1975;250:6134-6140.

[10]. Kitazawa $\mathrm{T}$.,Teneike $\mathrm{T}$ and Ohga A.Functional motilin receptor in the chicken proventriculus and ileum.Regulatory peptides.1997;71(2,15):87-95.

[11]. Kulkarni SK. Editor. Handbook of Experimental pharmacology. 3rd Edition. New Delhi: Vallabh prakshan;1999.Experiments on isolated preparations; $\mathrm{CH}-3: 85-110$.

[12]. Liu L and Burcher E.Radioligand binding and functional characterisation of of tachykinin receptors in chicken small intestine.Naunyn-Schmeideberg's archeives of pharmacology.2001;364(4):305-313. 
[13]. Malaisse WJ.Insulin secretion-Multifactorial regulation for a single process of release.Diabetologia.1973;9:167-173.

[14]. Martin Mt .,Fernandez AG .,Fernandez E .,Gonalons E.Receptors implicated in the actions of serotonin on chicken ileum longitudinal smooth muscle.Life Sciences. 1993;52(16):1361-1369.

[15]. Milner RDG and Hales CN.The role of calcium and magnesium in insulin secretion from rabbit pancreas studied invitro.Diabetologia.1967;3:47-49.

[16]. Naber SP and Hazelwood RL.In-vitro insulin release from chick pancreas.General and Comparative Endocrinology.1977;32(4):495504.

[17]. Otsu K .,Tada M.Calcium release channel of cardiac muscle sarcoplasmic reticulum.Nihon Rinso..Review.Japanese .PubMed.1993;.June 51(6):1491-1495

[18]. Pasanen S .,Ylikomi T .,Syvala H .,Tuohimaa P.Distribution of progesterone receptor in chicken novel target organs for progesterone and estrogen action.Molecular and Cellular endocrinology.1997;135(1):79-91.

[19]. Pust MH.Effect of galanin on smoothmuscle of chicken ileum in-vitro.Bios @ Beta Beta Beta Biological Society.1996;67(4):202-208.

[20]. Salola S .,Pekki A .,Sannisto T .,Ylikomi T .,Tuohimaa P.Progesterone receptor is constitutively expressed in chicken intestinenmesothelium and smooth muscle.Journal of Steroid Biochemistry.1989;34(1-6):345-349.

[21]. Tanobe, V.O.A, Sydenstricker, T.H.D., Munaro, M., and Amico, S.C. 2005. A comprehensive characterization of chemically treated Brazillian sponge-gourds (Luffa cylindrica). Polym. Test, 24 (4): 474-482.

[22]. Wolheim CB .,Blondel B .,Trueheart PA .,Renold AE and Sharp GWC.Calcium induced insulin release in monolayer culture of endocrine pancreas:Studies with ionophore A23187.J.Biol.Chem.1975;250:1354-1360.

[23]. Zhang F .,Dey D .,Branstrom R .,Forsberg L .,Lu M .,Zhang Q and Sjoholm A.Blx-1002,a novel thiazolidinedione with no PPAR affinity,stimulates AMP-activated protein kinase activity,raises cytosolic $\mathrm{Ca}^{++}$and enhances glucose stimulated insulin secretion in a PI-3K dependent manner.Am.J.Physiol cell.Physiol.2009;296:346-354. 